\title{
ANALYSIS OF THE EFFECT OF INFLATION ON MUDHARABAH SAVING RESULTS AT MANDIRI SHARIA BANK 2015-2020
}

\author{
Isthi Tresna Aristhantia \\ Institut Agama Islam Darussalam (IAID) Ciamis-Jawa Barat \\ Email: isthi.tresnaaristhantia@iaid.ac.id \\ Jajang Saeful Hikmat \\ Institut Agama Islam Darussalam (IAID) Ciamis-Jawa Barat \\ Diki Rahmat Awaludin \\ Institut Agama Islam Darussalam (IAID) Ciamis-Jawa Barat
}

\begin{abstract}
This research was conducted to determine how the effect of inflation on revenue sharing from the Musyarakah financing contract, how the effect of operating costs on revenue sharing from the Musyarakah financing contract, and how the effect of inflation and operating costs together on revenue sharing from the financing contract. musharakah at PT. Bank Jabar Banten Syariah. This research is quantitative. The sample used in this study is in the form of monthly financial statements of PT. Bank Jabar Banten Syariah for the period 2017-2021 published on the official website of Bank Indonesia, the Financial Services Authority, and Bank Jabar Banten Syariah. The type of research data is secondary data. The results showed that partially inflation and operating costs had a positive and significant effect on revenue-sharing for the results of musyarakah financing. Taken together, inflation and operating costs have an impact on revenue-sharing from the Musyarakah financing contract, as evidenced by the probability-F statistic of 0.000038 , which is much smaller than 0.05. Then the contribution of the variable inflation and operating costs to the income of musyarakah financing is 0.275489 or (27\%). At the same time, the remaining $73 \%$ is explained by other variables that are not examined or are not included in this research model.
\end{abstract}

\begin{abstract}
Abstrak
Penelitian ini dilakukan untuk mengetahui bagaimana pengaruh inflasi terhadap pendapatan bagi hasil dari akad pembiayaan musyarakah, serta bagaimana pengaruh biaya operasional terhadap pendapatan bagi hasil dari akad pembiayaan musyarakah, dan juga bagaimana pengaruh inflasi dan biaya operasional secara bersama-sama terhadap pendapatan bagi hasil dari akad pembiayaan musyarakah pada PT. Bank Jabar Banten Syariah. Penelitian ini adalah penelitian kuantitatif. Sampel yang digunakan dalam penelitian ini adalah berupa laporan keuangan perbulan PT. Bank Jabar Banten Syariah periode 2017-2021 yang dipublikasikan di website resmi Bank Indonesia, Otoritas Jasa Keuangan, dan Bank Jabar Banten Syariah. Jenis data penelitian adalah data sekunder. Hasil penelitian menunjukkan bahwa secara parsial variabel inflasi dan biaya operasional berpengaruh positif dan signifikan terhadap pendapatan bagi hasil pembiayaan musyarakah. Secara bersama-sama variabel inflasi dan biaya operasiona berpengaruh terhadap pendapatan bagi hasil dari akad pembiayaan musyarakah, yang dibuktikan dengan nilai probability-F statistic sebesar 0,000038 yang jauh lebih kecil dari o,05. Kemudian kontribusi variabel inflasi dan biaya operasional terhadap pendapatan pembiayaan musyarakah adalah sebesar o,275489 atau (27\%) sedangkan sisanya sebesar 73\% dijelaskan oleh variabel lain yang tidak diteliti atau tidak dimasukan dalam model penelitian ini.
\end{abstract}


Keywords: Inflation, Operational Costs, Musyarakah Financing

\section{Introduction}

The monetary crisis in Indonesia has caused several conventional banks to be liquidated because they cannot carry out their obligations to customers due to the highinterest policy set by the government. The high-interest policy issued by the government aims to suppress the inflation rate in Indonesia, which is already out of control.

The impact of uncontrolled inflation causes conventional banks to need more funds to pay their obligations to customers. It is what causes the national economy to worsen and conventional banks to be closed by the government. In contrast to Islamic banks, which proved not to be significantly affected by the monetary crisis in 1998 because they did not have an obligation to pay interest to their customers. Islamic banks only pay profit sharing to their customers following the profits the bank gets from their investments.

So far, the government has encouraged and assisted the development of Islamic banks by issuing Law No. 10 of 1998, which states that Indonesia adheres to a dual banking system, after that in 2006, Bank Indonesia Regulation (PBI) No. 8/3/PBI/2006 was issued regarding changes in activities. conventional commercial banks to become commercial banks that carry out actions based on sharia principles and open sharia activities offices by conventional commercial banks.

Seeing the large opportunity for Muslims in Indonesia and the needs of the Muslim community for sharia-compliant financial institutions, PT Bank Jabar Banten finally established a sharia business unit, namely Bank Jabar Banten Syariah, which was established on January 15, 2015.

The bank's income from this musyarakah financing will be greatly affected by the economic conditions and policies issued by the government, both in the form of fiscal policy and monetary policy. The policy issued by the government that affects banks is inflation. If inflation occurs, there will be uncertainty in a country's macroeconomic conditions, which causes people to use their funds more for consumption and speculation. High prices and fixed income that does not increase following the amount of inflation makes people not have excess funds to be deposited in the bank, even customers will have the potential to withdraw money from the bank, so this will reduce the amount of money in the bank which will have an effect as well on liquidity and the portion of financing that will be carried out by the bank when the part of the financing in the bank is reduced it will also affect how much income will be obtained by the bank.

Meanwhile, other factors that affect revenue sharing from Musyarakah financing besides inflation are operational costs, because operational costs in financing activities are charged to the shared capital that is deposited, so when the company's operations are large, the capital used is also large, this will affect the amount of money, which the bank will use for financing. Operational costs are sacrifices or costs incurred to carry out a company's operating activities with certain aims and objectives.

This is reinforced by several previous studies from AN Fauziyah (2021) IAIN Tulung Agung on "The Influence of Operational Costs, Inflation, and Gross Domestic Product on Musyarakah Financing" that the result is that the inflation variable has no positive and insignificant effect on musyarakah financing, and the cost variable operational has a positive and significant effect on musyarakah financing. 
In another study examined by Fahruddin (2009) UIN Sunan Kalijaga Yogyakarta on "The Influence of Capital Adequacy Ratio Inflation, Credit Risk, Third Party Funds and Networks on Financing at Islamic Commercial Banks in 2006-2008". The results of the inflation variable have a positive and significant effect on Islamic commercial bank financing in Indonesia.

\section{Theoretical Review}

The Inflation Concept

Inflation is defined as an increase in prices in general and continuously. An increase in the price of one or two goods alone cannot be called inflation unless the increase extends (or causes price increases) to other goods. In general, inflation means an increase in the general price level of goods/commodities and services during a certain period of time. This increase in the price level coincides with the decline in the real value of the country's currency.

The Concept of Operating Costs

According to Sumarsan (2018:103) cost is cash or cash equivalent value sacrificed for goods or services that are expected to provide current or future benefits for the organization. It is called cash equivalent because non-cash sources can be exchanged for the desired goods or services. While the expense (expense) is the cost used (expired cost). According to Nafarin (2004:379), cost is the value of something that is sacrificed, measured in units of money to obtain assets that are offset by a reduction in assets or an increase in debt or capital. According to Sumarsan (2018: 105) operational costs are operating expenses, namely costs in the form of spending money to carry out main activities, namely in the form of selling and administrative costs to obtain income, excluding expenses that have been calculated in the cost of goods sold and depreciation.

So operational costs are all the sacrifices issued by the company to fund the company's operating activities to achieve the goals to be achieved by the company. Operational costs are related to the company's operations outside of production costs, including marketing costs and general and administrative costs.

The Concept of Musyarakah Profit Sharing Financing Income

According to Law No. 10 of 1998, financing is the provision of money or an equivalent claim, based on an agreement or agreement between the bank and another party that requires the party being financed to return the money or claim after a certain period of time in exchange for or for results. According to Antonio (2001:160), financing is the provision of facilities to meet the needs of parties in a unit deficit.

According to foreign terminology (English), profit sharing is known as profit sharing. Profit in the economic dictionary is defined as profit sharing. Profit-sharing etymologicaly is profit sharing (Muhammad, 2002:101). According to Antonio (2001: 90), "profit sharing is a system of processing funds in the Islamic economy, namely the distribution of business results between the owners of capital (shahibul maal) and managers (mudharib)."

The legal basis for conducting musharakah is as follows:

Al-Qur'an Surah An-Nissa (12):

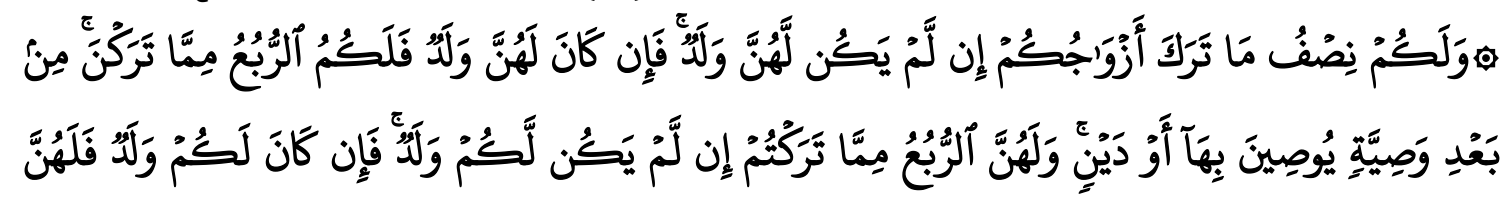




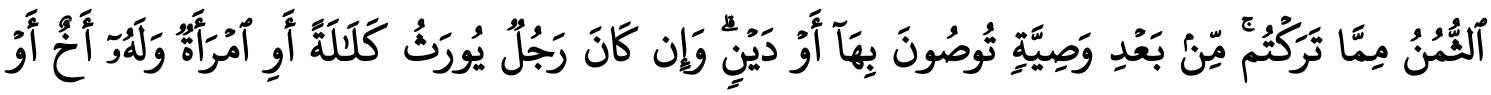

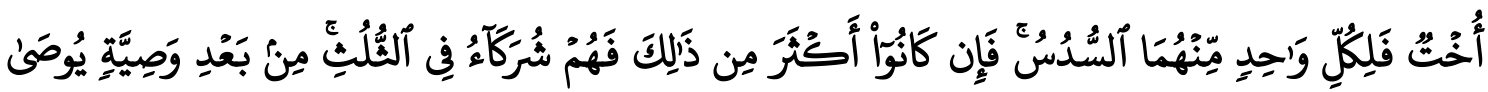

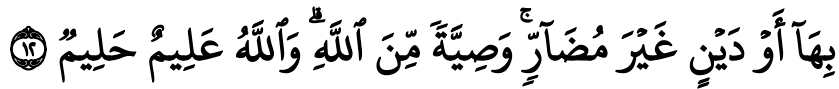

And for you (husbands) half of the property left by your wives, if they do not have children. If your wives have children, then you will get a quarter of the property left by them after their will has been fulfilled or (and) the debt has been paid. The wives get a quarter of the property that you leave if you do not have children. If you have children, then the wives get an eighth of the property that you leave after fulfilling your will or (and) after paying your debts. If someone dies, good a man or a woman who does not leave her father and does not leave children, but has a brother (only one mother) or a sister (only one mother), then for each of the two types of relatives one-sixth of the property. But if the mother's brothers are more than one, then they are partners in the third one, after fulfilling the will made by him or after paying the debt by not giving harm (to the heirs). (God established that as) the true Shari'ah from Allah, and Allah is All-Knowing, Most Forbearing." (Surat an-Nissa: 12).

\section{Methods}

The research method is a scientific way to obtain data with certain goals and uses. The data needed in a study must be in accordance with valid, reliable and objective criteria. For the research carried out in accordance with the applicable rules and lead to the desired results, the method used must be precise and correct. According to Sujarweni (2020:12), quantitative research produces findings that can be achieved using statistical procedures or other means of quantification (measurement).

The type of research used in this research is quantitative research. In a quantitative approach, the nature of the relationship between variables is carefully analyzed using an objective theory. The method used in this research is associative research (relationship). Associative research aims to determine the relationship between two or more variables (Sujarweni, 2020:49). With this research, a theory can be built that states how strong the relationship or influence of the independent variable $(\mathrm{X})$ is to the dependent variable $(\mathrm{Y})$.

In this study, the author wants to see the relationship between inflation and operating costs on revenue sharing from Musyarakah financing at Bank Jabar Banten Syariah from the 2017-2021 time period.

Data was analyzed by multiple linear regression. According to Hartono (2016: 110), multiple regression is useful for finding the effect of two or more predictor variables, finding a functional relationship between two or more predictor variables on the criterion variable, or predicting two or more predictor variables on the criterion variable. In this study, multiple linear regression analysis was used to prove the extent of the influence of inflation and operating costs on revenue sharing of musyarakah financing.

\section{Results and Discussion}

This descriptive statistic is used to see an overview of the data used. The table below shows descriptive statistics on the variables generated by the processed Eviews 8 
in this thesis research. Based on data, it states that the variable $\mathrm{X} 1$ operating costs (BOP) has a minimum value of $1.21 \mathrm{E}+10$, the median value (median) is $1.25 \mathrm{E}+11$, the maximum value is $2.18 \mathrm{E}+12$, and the average value (mean) is ) of $3.08 \mathrm{E}+11$. Variable $\mathrm{X} 2$ inflation has a minimum value of 0.027900 , a median value of 0.048600 , a maximum value of 0.087900 , and an average value (mean) of 0.055153 . The variable $Y$ (musyarakah) has a minimum value of $4.29 \mathrm{E}+09$, a median value of $3.93 \mathrm{E}+10$, a maximum value of $1.10 \mathrm{E}+11$, and an average value (mean) of $1.10 \mathrm{E}+11$.

The normality test used in this study aims to test whether the data to be processed by the researcher is normally distributed or not. Processed results of normality test using Eviews 8 . The decision whether the residual is normally distributed or not is simple by comparing the calculated JB (Jarque-Bera) probability value with an alpha level of 0.05 (5\%). When Prob. JB count greater than 0.05, it can be concluded that the residuals are normally distributed and vice versa, if the value is smaller then there is not enough evidence to state that the residuals are normally distributed.

The hypothesis used: Ho: residual data is not normally distributed. Ha: residual data is normally distributed. Prob value of JB count is $0.287722>0.05$, so it can be concluded that rejecting $\mathrm{Ho}$ and accepting $\mathrm{Ha}$, which means that the residual data is normally distributed, means that the normality of the data has been met.

The multicollinearity test aims to test whether there is a correlation between the independent variables in the regression model or not. The processed results of the multicollinearity assumption test using Eviews 8 can be said, based on result, it is known that the VIF value of the inflation and operating costs variables is 1.247108. These results indicate that the inflation and operating costs variables are free from the classical assumption of multicollinearity, because the results are smaller than 10.

The heteroscedasticity test is used to determine whether or not there is a deviation from the classical assumption of heteroscedasticity, namely the existence of an inequality of variance from the residuals for all observations in the regression model. The processed results of the multicollinearity assumption test using Eviews 8 can be said that it is explained that if the value of probability. The calculated $\mathrm{F}$ is greater than the alpha level of 0.05 (5\%), then Ho is accepted, which means there is no heteroscedasticity, whereas if the Prob value. F count is smaller than the alpha level of 0.05 (5\%), then Ho is rejected, which means there is heteroscedasticity. Based on the result, the calculated $\mathrm{F}$ of 0.0701 is greater than the alpha level of 0.05 (5\%). Based on the hypothesis test, Ho is accepted and Ha is rejected, which means that there is no problem with the classical assumption of heteroscedasticity.

The autocorrelation test. The processed results of the classical assumption of autocorrelation using Eviews 8 show that the Durbin Watson (DW) value is 1.8006. In the DW table for the number of observations $(n)=60, K^{\prime}=2$ and a significance of $5 \%$, the $\mathrm{dL}$ value is 1.5144 and $\mathrm{dU}$ is 1.6518 . So that in the regression equation model, the value of DW is in the area $\mathrm{dU}<\mathrm{d}<4$-dU. Then Ho is accepted, meaning that the DW value is in the criteria of no conclusion. Thus the assumption of autocorrelation in the regression equation model has been fulfilled. The autocorrelation test carried out with the Durbin-Watson test can be stated that the value of $\mathrm{DW}=1,800$ is greater than $\mathrm{dU}=$ 1,651 and less than $4-\mathrm{dU}=2,348$. So it can be concluded that the data used in this study is free from autocorrelation problems. 
Multiple regression is useful for finding the effect of two or more predictor variables or for finding a functional relationship between two or more predictor variables on the criterion variables. The processed results of multiple linear regression analysis using Eviews 8 can be said, the constant a of -7.32 states that if the value of inflation (X1) and operating costs (X2) is constant (o) then the variable value of Musyarakah financing income (Y) is $-7.32 \%$. The value of the regression coefficient $\mathrm{X} 1$ has a positive relationship of 0.024704 for the inflation variable, meaning that for every $1 \%$ increase in inflation, the revenue sharing for Musyarakah financing will increase by $0.024704 \%$, and vice versa if inflation decreases by $1 \%$, then the revenue-sharing financing results Musyarakah is also predicted to decrease by $0.024704 \%$. in this case other influential factors are considered constant.

The value of the regression coefficient X2 has a positive relationship of 7.72 for the operational cost variable. For every $1 \%$ increase in operating costs, income will increase by $7.72 \%$, and vice versa if operating costs decrease by $1 \%$, then revenue sharing is financing. Musyarakah is also predicted to decrease by $7.72 \%$, in this case other influential factors are considered constant.

The t-test was used to partially test the hypothesis in order to show the effect of each independent variable individually on the dependent variable. The t-test in multiple linear regression is intended to test whether the parameters (regression coefficients and constants) that are thought to estimate the multiple linear regression equation/model are the right parameters or not.

The effect of inflation on musyarakah financing income can be explained that to test the significance of the inflation variable on musyarakah financing with the following guidelines: $\mathrm{Ho}=$ There is no significant effect of inflation variable on musyarakah financing. $\mathrm{Ha}=$ There is a significant effect of inflation variable on musyarakah financing. Based on the Coefficient table above, a significance value of 0.0000 is obtained with a t-count value of 4.399628 . Because the value of Sig. $<$ and $t$ arithmetic $>\mathrm{t}$ table, it can be concluded that reject Ho and accept Ha. Thus, the inflation variable has a positive and significant effect on musyarakah financing.

The results of this study are following previous research conducted by Fahruddin (2009) entitled "The effect of inflation, capital adequacy ratio, credit risk, third party funds and networks on financing at Islamic commercial banks in 2006-2008" that the results of the inflation variable have a positive and positive effect. significant to the financing of Islamic commercial banks.

Then in Sofyan's research (2016) with the title "The influence of per capita income, interest rates, the money supply and inflation on the amount of savings in Indonesia" that the results of his research on the inflation variable have a positive and significant effect on the amount of savings in Indonesia.

From the result, it can be explained that to test the significance of the operational cost variable on musyarakah financing with the following guidelines: $\mathrm{Ho}=$ There is no significant effect between operational costs on musyarakah financing. Ha = There is a significant influence between operational costs on musyarakah financing. Based on the coefficient table, a significance value of 0.0002 is obtained with a t-count value of 3.976215. Because the value of Sig. < and $t$ arithmetic $>t$ table, it can be concluded that accept $\mathrm{Ha}$ and reject Ho. Thus, it means that the operational cost variable has a positive and significant effect on musyarakah financing. 
The results of this study are in accordance with previous research conducted by Fauziyah (2021) regarding "The effect of operating costs, inflation, and Gross Domestic Product on Musyarakah financing" that the results of operational cost variables have a positive and significant effect on Musyarakah financing. Then in Purwaningsih's (2015) research entitled "Analysis of external factors and internal factors that affect murabahah financing margins" that operational costs (BOP) have a positive and significant effect on Bank Muamalat Indonesia (BMI) murabahah financing margins.

In the simultaneous test, the effect of the two independent variables together on the dependent variable will be tested. The results obtained from statistical tests using Eviews 8 that have been carried out can be seen in Table 15.1 with the following details: The guidelines used are: if Sig. < then Ho is rejected, which means that there is a linear relationship between inflation and operational costs on musyarakah financing. Generally this output is used to test the hypothesis. The hypothesis used is: Ho = There is no significant effect between inflation and operational costs on musyarakah financing. $\mathrm{Ha}=$ There is a significant influence between inflation and operational costs on musyarakah financing. From table 15.1 the results of the F test above, the F statistic value is 12.21714 with a probability level of 0.000038 . Because the probability (0.000038) is much smaller than 0.05 (in this case using the significance level or $=$ $5 \%$ ), it can be concluded that Ha is accepted and Ho is rejected. So it can be said that together the variables of inflation and operating costs have a significant effect on the variable of musyarakah financing income.

The results of this study are following previous research conducted by Fauziyah in 2021 on the effect of operational costs, inflation, and Gross Domestic Product on musyarakah financing, that the result is that the inflation variable, operational costs have a positive and significant effect on musyarakah financing.

Coefficient of Determination Analysis (KD) is used to see how much the independent variable (X) has an impact on the dependent variable $(\mathrm{Y})$ which is expressed as a percentage. R2 hypothesis testing can be said that for multiple linear regression, it is better to use an adjusted $\mathrm{R}$ square or written Adjusted R Square, because it is adjusted to the number of independent variables used.

From results, it is known that the Adjusted $\mathrm{R}$ square number or coefficient of determination is 0.275489 , which means that the inflation variable and operating costs together have a contribution to the Musyarakah financing income of $27.55 \%$ while the remaining $72.45 \%(100 \%-27.55 \%)$ is influenced by other variables that are not studied or are not included in this research model.

According to Gilarso (2004:200), inflation is an increase in the price level originating from the disruption of the balance between the flow of money and the flow of goods, which means that inflation increases in the general price level of goods/commodities and services during a certain period of time. Inflation has a negative impact on people's welfare, one of which is to reduce the value of wealth in the form of money (Murni 2007:206).

Inflation is defined as the overall increase in goods or service commodities. The higher inflation will cause people's purchasing power to decrease, because of high prices. To contain the increasing rate of inflation, Bank Indonesia (BI) issued a policy reference interest rate, which is a reference for banks to determine the interest rate 
issued by banks. In addition, attracting too much money circulating in the community will cause economic growth to be faster and inflation will be controlled.

Based on the research results above, it shows that inflation has a positive and significant effect on musyarakah financing. It is evidenced by the statistical test results using Eviews 8 with a Sig value. less than and $t$ count is more than $t$ table, it can be concluded that $\mathrm{Ho}$ is rejected and $\mathrm{Ha}$ is accepted, which means that the initial hypothesis about the effect of inflation on Musharaka financing income at Bank Jabar Banten Syariah is acceptable.

Thus, it means that the inflation variable has a positive and significant effect on musyarakah financing. This indicates that when inflation increases, the income of musharaka financing also increases, and vice versa, if inflation decreases, the income of musyarakah financing will decrease. The results of this study are in accordance with previous research conducted by Fahruddin (2015) entitled "The effect of inflation, Capital Adequacy Ratio, Credit Risk, third party funds and networks on financing at Islamic commercial banks in 2006-2008" that the results of the inflation variable have a positive and positive effect. significant to the financing of Islamic commercial banks.

Then in Sofyan's research (2016) entitled "The effect of per capita income, interest rates, money supply and inflation on the amount of savings in Indonesia" that the results of his research on the inflation variable have a positive and significant effect on the amount of savings in Indonesia.

Then in another study Priatmadja (2016) with the research title "The effect of inflation on non-performing financing per contract and per economic sector in Islamic bank X" with research results, the inflation variable has a positive and significant effect on non-performing financing and per economic sector.

With an increase in inflation, it will be followed by an increase in interest rates. With high interest rates it is expected that prospective customers are willing to place their funds in banks because the interest they earn is higher, with more funds absorbed by banks, banks will be more flexible in issuing financing. towards its customers. The higher the level of financing issued by the bank, the income to be received by the bank will increase.

According to Rudianto (2006:20) operational costs are costs related to the company's operations outside of production costs. Operational costs include two groups of costs, namely marketing costs and general and administrative costs. administrative and general costs are costs incurred for operational purposes such as office stationery, credit administration costs and other administration (Kasmir, 2005:147). In carrying out a financing, there will definitely be operational costs which are costs charged to customers because they have used banking services in conducting financing. The greater the customer's operational costs, the greater the total revenue from musharaka financing.

Based on the results of research that has been carried out, that the results of operational costs have a positive and significant effect on the income of musyarakah financing. This is evidenced by statistical testing using Eviews 8 with a Sig value. less than and $t$ count is more than t table, it can be concluded that Ho is rejected and Ha is accepted. This is in line with the initial hypothesis that operational costs affect the income of musyarakah financing at Bank Jabar Banten Syariah acceptable.

Thus, it means that the operational cost variable has a positive and significant effect on the income of musyarakah financing. This indicates that each addition to 
operational costs, the income of musyarakah financing increases as well. And vice versa, if there is a decrease in operational costs, the income of musyarakah financing will also decrease.

The results of this study are in line with Purwaningsih's (2015) research that operational costs (BOP) have a significant effect on the murabahah financing margin of Bank Muamalat Indonesia, with a probability value smaller than the critical value, meaning that an increase will follow each addition of the operational cost variable (BOP) in the financing margin. murabahah of Bank Muamalat Indonesia. Then this research is in line with Fauziyah's (2021) research on "The effect of operating costs, inflation, and gross domestic product on Musyarakah financing" that the results of operational cost variables have a positive and significant effect on Musyarakah financing.

Based on the multiple linear regression equation, the results are that every increase (because it is positive), inflation will increase the value of Musyarakah financing income and vice versa. If inflation decreases, Musyarakah financing income is predicted to decrease. In the operational cost variable, the results of a positive influence on musyarakah financing income are obtained, so when operational costs increase, the amount of income received by banks increases, on the contrary when operational costs experience a decrease in musyarakah financing income, it is also predicted to decrease the results of the hypothesis prove this. The $\mathrm{F}$ test obtained a statistical $F$ value of 12.21714 with a probability level of 0.000038 . Because the probability (0.000038) is smaller than 0.05, it can be concluded that Ha is accepted and Ho is rejected. So it can be said that together the variables of inflation and operating costs have a significant effect on the variable of musyarakah financing income. This is in line with the initial hypothesis which states that inflation and operating costs affect the income of musyarakah financing at Bank Jabar Banten Syariah which is acceptable.

Then based on the analysis of the coefficient of determination, it can be seen that the Adjusted R-square value is 0.275489 , which means that the inflation variable and operating costs together have a contribution to the Musharaka financing income of $27.55 \%$, while the remaining $72.45 \%(100 \%-27,55 \%)$ is influenced by other variables that are not studied or are not included in this research model. This research is in line with Fauziyah's (2021) research on "Effect of operating costs, inflation, and gross domestic product on musyarakah financing" because the results of operational costs, inflation and gross domestic product jointly have a positive and significant effect on the dependent variable (musyarakah financing).

\section{Conclusion}

Based on the research and discussion results that have been stated above, the following conclusions can be drawn: (1) The independent variable inflation has a positive and significant influence on the income of Musyarkah financing at Bank Jabar Banten Syariah. This means that the proportion of musyarakah financing income will increase when inflation increases. (2) The independent variable operating costs has a positive and significant influence on the income of musyarakah financing at Bank Jabar Banten Syariah. This means that the higher the operational costs incurred by the bank, the higher the proportion of musyarakah financing income at Bank Jabar Banten 
Syariah. (3) Based on the joint test, the independent variables of inflation and operating costs positively and significantly affect the dependent variable, namely Musharaka financing income. The results of the R2 test prove that inflation and operating costs have a contribution to the income of musyarakah financing by $27.55 \%$, while the remaining $72.45 \%(100 \%-27.55 \%)$ is influenced by other variables not examined or not included in this research model.

\section{REFERENCES}

Antonio, S.M. (2016). Bank Syariah: Dari Teori Ke Praktik. Jakarta: Gema Insani Dan Tazkia Cendekia.

Arif Al Rianto,N.M. (2017). Lembaga Keuangan Syariah. Bandung: Cv Pustaka Setia.

Atmadja, a. (2004). Iinflasi di Indonesia: sumber-sumber penyebab dan pengendalianya

Bank Bjb syariah. 2021, di akses http//www.bjbsyariah.co.id/tentang-bjb-syariahsejarah. Pada tanggal 10 Desember 2021

Bank Indonesia. (2021), di akses http//www.bi.go.id. Pengenalan Inflasi Oleh Bank Indonesia. pada tanggal 10 Desember 2021.

Fauziyah. (2021). Pengaruh Biaya Operasional, Inflasi, Dan Produk Domestik Bruto Terhadap Pembiayaan Musyarokah.IAIN Tulung Agung. Tulung Agung.

Fahrudin, Zaki Muhamad. (2009), Pengaruh Inflasi Capital Adequacy Ratio, Credit Risk, Dana Pihak Ketiga dan Jaringan Terhadap Pembiayaan Pada Bank Umum Syariah Tahun 2006-20o8.UIN Sunan Kalijaga:Yogyakarta.

Gilarso, T. (2004). Pengantar Ekonomi Mikro. Yogyakarta: Kanisius.

Ghozali, Imam. (2018). Aplikasi analisis multivariate dengan Program SPSS.Semarang. Badan Penerbit Universitas Diponegoro.

Hatta. (2008). Telaah Singkat Pengendalian Infasi Dalam Perspektif Kebijakan Moneter Islam.

Hartono. (2016). Analisis Data Statistika dan Penelitian, Yogyakarta: LSFK2P bekerja sama dengan Pustaka Pelajar.

Huda, N. dan Haykal, M. (2015). Lembaga Keuanagn Islam: Tinjauan Teoritis Dan Praktis. Jakarta: Fajar Interpratama Offset.

Kasmir. (2005). Pemasaran Bank. Jakarta:Kencana.

Muhamad. (2002). Manajemen Bank Syariah. Yogyakarta: UPP AMPYKPN.

Mulyadi. (2005). Akuntansi Biaya, edisi ke-6. Yogyakarta: STIE YKPN.

Murni, Asfia. (2018). Ekonomika Makro. Bandung: PT Refika Aditarma.

Nafarin. (2004). Penganggaran Perusahaan. Jakarta: Saemba Empat

Nasution, E. M. (2015). Pengenalan Ekslusif Ekonomi Islam. Jakarta: Fajar Interpratama Offset.

Purwaningsih. (2015). "Analisis Faktor Eksternal dan Faktor Internal yang mempengaruh

Margin Pembiyaan Murabahah". Dalam http://repository.uinjkt.ac.id/dspace/ bitstream /123456789/3933/1/LIN\%20 PURWANINGSIH-FEB.pdf Diakses 22 februari 2017

Priatmadja, Sadhana. "Pengaruh Inflasi Terhadap Pembiayaan Bermasalah Per Akad Dan Per Sector Ekonomi Di Bank Syariah X”. 2016. Dalam 
http://related:lib.ui.ac.id/file?file=digital/20295581-T29905-

Pengaruh\%20Inflasi.pdf diakses 22 Februari 2017

Rozalinda. (2020). Ekonomi Islam: teori dan aplikasinya pada aktivitas ekonomi. PT raja grafindo persada. Jakarta.

Rudianto,( 2006). Akuntansi Manajemen, Jakarta:PT Grasindo Anggota Ikapi.

Sakti, Haidar Sabana. "Pengaruh Biaya Operasionla Dan Tingkat Suku Bunga Terhadap Margin Pembiayaan Murabahah Pada PT. Bank Mega Syariah Indonesia" Dalam Http://Digilib.Uinsuka.Ac.Id/13747/1/BAB\%20I,\%2OV,\%2ODAFTAR\%2OPUSTAKA.Pdf, 2019. Diakses 22 Februari 2017

Sofyan, Muhammad. (2016). "Pengaruh Pendapatan Perkapita, Tingkat Suku Bunga, Jumlah Uang Beredar Dan Inflasi Terhadap Jumlah Tabungan Di Indonesia”.

Sumarsan Thomas. (2018). Sistem pengendalian manajemen: konsep, aplikasi dan pengukuran kinerja, edisi 2 . pt.indeks:Jakarta.

sugiyono. (2019). Metode Penelitian Kuantitatif, Kualitatif, dan Kombinasi (Mixed Method). Bandung: AVABETA, cv.

Sujarweni, V. W. (2020). Metodologi Penelitian Bisnis dan Ekonomi. Yogyakarta: Pustakabarupress.

Sutanto, Herry \& Umam, Khaerul. (2018). Manajemen Pemasaran Bank Syariah. Bandung: Pustaka Setia 
